\title{
The Sociology of Knowledge, Citizenship and the Purification of Politics
}

\author{
Jed Donoghue, Bob White \\ School of Sociology and Social Work, University of Tasmania, Hobart, Australia \\ Email: jedonogh@utas.edu.au
}

Received June $5^{\text {th }}$, 2012; revised September $8^{\text {th }}$, 2012; accepted September $21^{\text {st }}, 2012$

\begin{abstract}
We reinterpret citizenship using Mannheim’s classical sociology of knowledge and through a more recent variant on them in Latour's argument that "we have never been modern" (Latour, 1991). On that basis, we understand citizenship as a recursive effect of disputes over belonging and membership (Isin, 2002), where those disputes entail the three forms of political rationality or "thought styles" which Mannheim and Latour variously suggested: the linearly individual rationality of liberalism; dialectically collective socialism; and culturally collective conservatism. Marshall defines citizenship as a "status bestowed on those who are full members of a community" (Marshall, 1973). He presents an image of evolutionary progress, from civil to political rights and finally to the social form, in Britain. We argue that Marshall was entangled in evolutionary and teleological images of citizenship. We reinterpret citizenship using Mannheim's classical sociology of knowledge. We suggest that sociologies of knowledge allow a re-reading of "citizenship" that can accommodate conceptual difficulties. Mannheim called into question the "progress" implied or stated in theories of "stages". He stressed instead the continuing interaction between different ways of knowing social reality, or between what he called "thought styles". We apply Mannheim to "citizenship" in order to lift two "purifications", so that humanity is both natural and political.
\end{abstract}

Keywords: Sociology of Knowledge; Citizenship; Purification and Politics

\section{Introduction}

We reinterpret citizenship using Mannheim's classical sociology of knowledge and through a more recent variant on them in Latour's argument that "we have never been modern" (Latour, 1991). On that basis, we understand citizenship as a recursive effect of disputes over belonging and membership (Isin, 2002), where those disputes entail the three forms of political rationality or "thought styles" which Mannheim and Latour variously suggested: the linearly individual rationality of liberalism; dialectically collective socialism; and culturally collective conservatism.

Aristotle's pragmatic view was that: “[w]hat effectively distinguishes the citizen proper from all others is his participation in giving judgment and in holding office" (Aristotle, 1962). In contrast, Marshall defines citizenship as a "status bestowed on those who are full members of a community” (Marshall, 1973). Citizenship also promotes equality and freedom to the extent to which rights and duties are sanctioned by the nation state. Although the struggle for rights is mentioned by Marshall, the "instruments of modern democracy", such as the courts, parliament and social services, are considered to have been "fashioned" by the upper classes and handed down from above, rather than "pulled out of their hands". This process allegedly limited the excesses of the capitalist economy and fashioned "progress" towards modern democracy, in Britain.

Marshall sees citizenship as consisting of three elements: civil, political and social (Marshall, 1973). He presents an image of evolutionary progress, from the civil to the political and finally to the social form, in Britain. Although civil rights es- tablished the "rule of law", Marshall recognized it was "flawed" by class prejudices and the unequal distribution of wealth and income. Although not perfect, for Marshall the rule of law proved to be the "solid foundation" for all further reforms and the "core" of modern citizenship. It promoted the rights of the individual over customs and statutes, which were considered a "menace to the prosperity of the nation". The growing demand for economic freedom caused changes to be made to the Common Law, which proved "elastic" enough to accommodate new social and economic attitudes. There appears to be a "dialectical” process at work in Marshall's "elastic" laws that evolve into the "solid" foundation of modern political citizenship.

We suggest that Marshall was tangled in evolutionary and teleological images of citizenship. He implies the progressive recovery of an innate human freedom and equality. It is impossible to avoid the teleological strain in the result but few writers have noted Marshall's assumptions of a stable human nature and the analytical rationality of political/economic man that also appears to be characteristic of the modern (Donoghue \& White, 2003). In his later work Marshall wrote of "value problems" in welfare-capitalism, in which he stressed the tensions between the democracy, welfare and capitalism of the "hyphenated society" (Marshall, 1981). He imbued citizenship with a cultural sense and suggested the interpenetration of its civil/ capitalist, political/democratic and social/welfare moments. However, both models entail intractable difficulties, which lead to the return and prioritization of rational political/economic man who is separate from human nature but is applied to an evolutionary political process.

We argue in the next section that sociologies of knowledge 
allow a re-reading of "citizenship" that can accommodate conceptual difficulties. Something must be held constant in the study of social change and the sociologies of knowledge allow us to hold constant the "how" of disputes over citizenship rather than the "what". As Turner argued it is "conceptually parsimonious to think of three types of resource: economic, cultural and political" (Turner, 1997), instead we suggest three types of "thought style" or political rationality to explain the dynamics of citizenship (Donoghue \& White, 2003).

\section{Sociology of Knowledge}

The fact that Marshall couched his citizenship models as tripartite gives his work an immediate fit with the sociology of knowledge, for Mannheim had used trinaries as an implicit design principle throughout his early work. This is not to say that Mannheim somehow "influenced" Marshall's work. Marshall became a sociologist "under the influence of Hobhouse" and he had already adopted Hobhouse's "threefold categorization of kinship, authority and citizenship as the basic principles of social order” (Marshall 1973). Marshall's approach was set before Mannheim came to the London School of Economics in the 1930s (Kettler \& Meja, 1995), but the fit between the two uses of threefold categorization is worth stressing.

Mannheim argued that knowledge emerges as a relation between the knower (subject), the known, and the to-be-known (object), where the subject was always an intersubject, the known was always selectively drawn from tradition, and the to-be-known was then always historically contingent. "Every epistemological systematization", he held, "is based upon this triad, and every conceivable formulation of the problem of knowledge is given by these three terms in some combination" (Mannheim, 1922). Although he objected to Kant's "fetish" for trichotomies he was to use a range of combinations in his sociology of knowledge (Mannheim, 1922). For all the limits of epistemology, Mannheim held that the self-relativisation in it was genealogically crucial to the sociology of knowledge. The individualising trend from Descartes cogito to Kant's account of the subject gave one element in any knowledge under study. It had been followed, interactively, by the attention to collective subjects in Marxist ideological analysis and by the emergence of "the social" as an "ontological terminus of the motion transcending theoretical immanence" (Mannheim, 1925). Those three genealogical moments were permanently coexistent rather than successive, and were fused in the "total relativisation" of the sociology of knowledge.

Mannheim depicted the sociology of knowledge as requiring three types of methods. It should be "scientific", for although positivism had remained at "a relatively primitive level" in the bourgeois and proletarian nuances of Durkheimian work and of materialism respectively, it remained valuable, ironically, for its metaphysics of "essential contact with reality" (Mannheim, 1925). Secondly, it should be hermeneutically focused on the Weltanschauung, or unified complex of meanings prevailing at a given time (Mannheim, 1925). Finally, it should be historicist. Taking Alfred Weber's distinction between "culture” and "civilization”, Mannheim held that the Gestalt of the former was open to hermeneutic understanding and the latter to causal analysis in the progressive terms of the Enlightenment. But he placed a third domain between culture and civilization, where "progress" was dialectical rather than immanently logical in the sense attributed to changes in technology or science, and his- toricism then required attention to three types of "developmental sequence":

Such a system, furthermore, is inescapably political and Mannheim linked his sociology of knowledge to political movements. The links between theory and practice that developed with the emergence of liberalism, socialism and conservatism were applied interdependently in the academy, and the study of the sociology of knowledge was entangled in broader conflicts (Mannheim, 1929). The sociology of knowledge was to be a "dynamic synthesis" of the tendencies summarized in the three political movements. Mannheim called into question the "progress" implied or stated in theories of "stages". He stressed instead the continuing interaction between different ways of knowing social reality, or between what he called "thought styles" (Mannheim, 1927). The structure of intellectual arguments was as crucial as what was argued. Trinary ordering being the next simplest way of classifying objects beyond the "either/or" and "before/after" found in analytically linear accounts of "progress".

\section{Purification of Politics}

In calling for a revival of Mannheim's work Pels has stressed its value as an exemplar of "third positions" beyond the oversimplification, which necessarily follows from the use of polar categories. For our purposes, we focus on the similar point, which Latour reached when he argued that "we have never been modern”. Although he did not mention Mannheim, Latour took a similar point of departure against dichotomies, advanced a similar argument for the relevance of the sociology of science studies as Mannheim had made for the sociology of knowledge, and presented a similar solution to the difficulty of studying knowledge.

"Dualism may be a poor solution”, Latour said, "but it provides 99 per cent of the social sciences critical repertoire, and nothing would have disturbed its blissful asymmetry if science studies had not upset the applecart” (Latour, 1991). The very word "modern" exemplifies the problem. Whenever it is used, "the word is always being thrown into the middle of a fight, in a quarrel where there are winners and losers, Ancients and Moderns. "Modern” is thus doubly asymmetrical: it designates a break in the regular passage of time, and it designates a combat in which there are victors and vanquished" (Latour, 1991).

Latour read the "modern" as defined by two forms of dichotomous "work of purification". In the first, an ontological distinction of the human from the non-human results in obliviousness to the hybrid character of the networks of nature/culture. Heterogeneously engineered from documents, devices and disciplined bodies, these networks have proliferated throughout the period known as "modernity". But technologies and texts do not enable the social in the way stressed in dualistic social science; rather, they are as constitutive of the social as are humans. Study of this effect, however, has been hindered by a second purification, the separation of the epistemological from the political senses of "representation".

The dispute between Hobbes and Boyle exemplifies this aspect of the "modern constitution": Hobbes set out a science of politics, from which science was excluded; Boyle barred politics from what was in effect a politics of science and technology (Latour, 1991; Shapin \& Schaffer, 1985). So long as that purification was sustained, with one set of specialists speaking for a denatured and purely human politics and another for a 
depoliticised nature and technology, the networked coemergence of nature and culture was obscured. But "we have never been modern" in the sense that the purification was not successful (Latour, 1991).

If that rejection of scientific dualism recalls Mannheim's rejection of dichotomies, Latour's alternative to dualism also recalls his triadic allowance for the ensuing complexity. When Latour described the networks of nature/culture and study of them as "simultaneously real like nature, narrated like discourse, and collective like society" (Latour, 1991) he posed the same methodological inclusion of interactive and incommensurable "thought styles" and the same "continually receding viewpoint" as in Mannheim's design. Despite a shift of emphasis, from Mannheim's political "thought” to more material practices, and despite a shift of focus, to the "hard" science that Mannheim generally bracketed, there is a generic link between the two sets of solutions to the problem of modernity. Just as Mannheim insisted, furthermore, that his sociology of knowledge was not only reflexively applicable to sociology at large but was necessary to it, Latour has campaigned for the lessons from science studies to be included in the practice of the discipline.

\section{Conclusion}

Citizenship is a contested concept and accounts of it are entangled in how modernity is understood. Latour's reading of the modern is certainly applicable to citizenship. Whether writers on citizenship couch their assumptions over human nature in Hobbes or Rousseau's terms, the purifying assumption is crucial. Humanity is divided from nature but somehow also evolves naturally. The evolutionary "social science" on which Marshall's theory rests has also been purified of politics and is then reapplied to politics as an apparently neutral metaphor.

Mannheim called into question the "progress" implied or stated in theories of "stages". He stressed instead the continuing interaction between different ways of knowing social reality, or between what he called "thought styles". The structure of intellectual arguments was as crucial as what was argued. Trinary ordering being the next simplest way of classifying objects beyond the "either/or" and "before/after" found in analytically linear accounts of "progress". We apply Mannheim to "citizenship" in order to lift those two purifications so that humanity is both natural and political. To allow for the essential contestability of "value charged" (White, 2000) concepts in the social sciences, we define citizenship in terms of Mannheim's "dynamic synthesis" of what is always political, temporal and socially "intentional”.

\section{REFERENCES}

Aristotle (1962). The politics. In T. A. Sinclair, \& T. J. Saunders (Eds.), Translators. London: Penguin.

Donoghue, J., \& White, R. D. (2003). Contested citizenship TASA conference. Armidale: University of New England.

Isin, E. (2002). Being political: Genealogies of citizenship. Minneapolis, MN: University of Minnesota Press.

Kettler, D., \& Volker, M. (1995). Karl Mannheim and the crisis of liberalism: The secret of these new times. New Brunswick: Transaction Press.

Latour, B. (1991). We have never been modern catherine porter. Cambridge, MA: Harvard University Press.

Mannheim, K. (1922). Structures of thinking. London: Routledge \& Kegan Paul.

Mannheim, K. (1925). The problem of a sociology of knowledge. In K. Wolff (Ed.), From Karl Mannheim (pp. 59-115). New York: Oxford University Press.

Mannheim, K. (1927). Conservative thought. In K. Wolff (Ed.), From Karl Mannheim (pp. 132-222). New York: Oxford University Press.

Mannheim, K. (1929). Ideology and Utopia: An introduction to the sociology of knowledge louis wirth and edward shills. San Diego: Harvest.

Marshall, T. H. (1973). Class, citizenship and social development. Westport, CT: Greenwood.

Marshall, T. H. (1981). Value-problems of welfare capitalism. In The right to welfare and other essays (pp. 104-122). New York: Free Press.

Pels, D. (1996). Karl mannheim and the sociology of scientific knowledge: Toward a new agenda. Sociological Theory, 14, 30-48. doi:10.2307/202151

Shapin, S., \& Simon, S. (1985). Leviathan and the air-pump: Hobbes, boyle, and the experimental life. Princeton, NJ: Princeton University Press.

Turner, B. S. (1997). Citizenship studies: A general theory. Citizenship Studies, 1, 5-18. doi:10.1080/13621029708420644

White, R. (2000). The life of class: A case study in a sociological concept. Journal of Sociology, 36, 223-238. doi:10.1177/144078330003600206 